\title{
Diagnosis of Shashi-Pena Syndrome Caused by Chromosomal Rearrangement Using Nanopore Sequencing
}

Ya Wang, PhD, * Jianxin Tan, PhD, * Yan Wang, PhD,* An Liu, MD, Fengchang Qiao, PhD, Mingtao Huang, PhD, Cuiping Zhang, MD, Jing Zhou, MD, Ping Hu, PhD, and Zhengfeng $\mathrm{Xu}, \mathrm{MD}$

Neurol Genet 2021;7:e635. doi:10.1212/NXG.0000000000000635

\section{Abstract}

\section{Background and Objectives}

The aim of this study was to uncover the genetic cause of delayed psychomotor development and variable intellectual disability in a proband whose previous genetic analyses, including chromosome microarray and whole exome sequencing, had been negative.

\section{Methods}

Long-read sequencing Oxford Nanopore Technology and RNA-seq analysis were performed on peripheral blood mononuclear cells. Genes with a fold change $\geq 1.5$ and $p \leq 0.05$ were identified as differentially expressed.

\section{Results}

Clinical examinations showed that the proband's features were similar to a rare autosomaldominant neurodevelopmental syndrome, Shashi-Pena syndrome (MIM \#617190). Karyotyping showed that a chromosomal balanced translocation $\mathrm{t}(2 ; 11)(\mathrm{p} 23 ; \mathrm{q} 23)$ was detected in the proband, her father, and her grandmother. Meanwhile, long-read sequencing identified 102 balanced translocations and 145 inversions affecting ASXL2 at an average of $15 \times$. Combined with the family's RNA-seq results, the average mRNA expression of ASXL2 decreased in the patients.

\section{Discussion}

We identified a complex chromosomal rearrangement affecting ASXL2 as a pathogenic mechanism of Shashi-Pena syndrome in a Chinese family. This case study suggests that nanopore sequencing is suitable for pathogenic analysis of complex rearrangements, providing new avenues for the diagnosis of genetic diseases.

\author{
Correspondence \\ Dr. Xu \\ zhengfeng_xu_nj@163.com
}

*Y. Wang, J. Tan, and Y. Wang contributed equally to this work.

From the Department of Prenatal Diagnosis, State Key Laboratory of Reproductive Medicine, Women's Hospital of Nanjing Medical University, Nanjing Maternity and Child Health Care Hospital, Nanjing, China.

Go to Neurology.org/NG for full disclosures. Funding information is provided the end of the article.

The Article Processing Charge was funded by NSFC.

This is an open access article distributed under the terms of the Creative Commons Attribution-NonCommercial-NoDerivatives License 4.0 (CC BY-NC-ND), which permits downloading and sharing the work provided it is properly cited. The work cannot be changed in any way or used commercially without permission from the journal. 


\section{Glossary}

CMA = Chromosome Microarray; ONT = Oxford Nanopore Technology; SMRT $=$ PacBio Single-molecule Real-time Sequencing; ID = Intellectual Disability; SVs = Structural variation; TRA = Balanced Translocations.

The ASXL (additional sex combs-like) gene family of epigenetic regulators including ASXL1 [MIM: 612990], ASXL2 [MIM: 612991], and ASXL3 [MIM: 615115] code for polycomb proteins that act as histone methyltransferases, ${ }^{1}$ serve as epigenetic scaffolding proteins, ${ }^{2}$ and participate in body patterning. ${ }^{3}$ ASXL1 gene mutations are frequently detected in myeloid neoplasms ${ }^{4,5}$ and cause Bohring-Opitz syndrome. ${ }^{6}$ ASXL3 gene mutations result in Bainbridge-Ropers syndrome (MIM \#615485). ${ }^{7}$ ASXL2 is conserved in Drosophila, mice, and humans and is part of the transcription regulation complex. ${ }^{8}$ However, ASXL 2 mutations are rarely reported in humans.

Previous reports have shown that ASXL2 mutants in 6 patients caused Shashi-Pena syndrome. ${ }^{3}$ All 6 had de novo truncating variants in ASXL2. The common clinical features in ShashiPena syndrome are neurologic and neurodevelopmental disorders with some facial features, whereas differences in the clinical phenotypes for each individual could be found.

Long-read sequencing technologies, such as Oxford Nanopore Technologies (ONTs) ${ }^{9}$ and PacBio single-molecule real-time sequencing, ${ }^{10}$ offer complementary strengths to traditional whole exome/whole genome sequencing based on short-read sequencing. Long-read sequencing can produce read lengths (typically $1-150 \mathrm{~kb}$ or longer) that are far higher than the $\sim 150$ bp produced by short-read sequencing, therefore allowing for the resolution of breakpoints of complex structural variations $(\mathrm{SVs}),{ }^{11}$ the detection of long tandem repeats, ${ }^{12}$ or DNA methylation on $\mathrm{N}^{6}$-adenine. ${ }^{13}$ Balanced translocations (TRA), a type of SVs, involve the exchange of genomic regions between nonhomologous chromosomes without the gain or loss of genetic material. Most TRA carriers are phenotypically normal, but the pathogenesis of abnormal TRA carriers remains unclear because of the technical limitations of detection. However, an association with abnormal phenotypes, including intellectual disability, developmental delay, and other congenital abnormalities, has been estimated in $6 \%-9 \%$ of de novo cases. ${ }^{14}$

We used ONTs to perform a genetic study of a proband (III-1) with developmental retardation, for whom a balanced translocation $\mathrm{t}(2 ; 11)$ (p23; q23) was identified by a chromosome karyotypic analysis, and negative results were found by chromosomal microarray analysis and whole exome sequencing. Moreover, RNA sequencing was carried out on peripheral blood of the whole family. By combining the results of the breakpoint candidate genes, RNAseq, and qPCR, we concluded that a complex rearrangement of the chromosomes decreased the mRNA expression of ASXL2 in the patients and led to a rare autosomal-dominant neurodevelopmental syndrome, Shashi-Pena syndrome.

\section{Methods}

\section{Standard Protocol Approvals, Registrations, and Patient Consents}

The samples of peripheral blood were taken from each patient on the same day. All procedures performed in studies involving human participants were in accordance with the Declaration of Helsinki and its later amendments or comparable ethical standards, with written informed consent obtained from all patients and their parents/guardians. The Research Ethics Committee of Nanjing Maternal and Child Health Hospital approved the study ([2019] KY-081).

\section{Study Design and Data Collection}

The proband is a 6-year-old girl who was admitted to our hospital at 3 years old because of speech delay. Her karyotype is $\mathrm{t}(2 ; 11)$ ( $\mathrm{p} 23 ; \mathrm{q} 23)$. Data were collected on her family history, medical history, and medications. The proband underwent a physical examination including length, weight, occipitofrontal head circumference, additional biochemical assays, Wechsler Intelligence test, Peabody test, X-ray examinations, and brain MRI.

\section{Molecular Testing and Variant Curation}

A DNA sample of the proband was sequenced using the Nanopore PromethION sequencer (ONTs, UK). Genomic DNA was extracted by QIAGEN genomic DNA extraction kit (Cat\#13323, QIAGEN). The extracted DNA was detected by NanoDrop 1 UV-Vis spectrophotometer (Thermo Fisher Scientific) for DNA purity (OD 260/280 ranging from 1.8 to 2.0 and OD 260/230 between 2.0 and 2.2); then a Qubit 3.0 Fluorometer (Invitrogen) was used to quantify DNA accurately. Long DNA fragments were size selected using the BluePippin system (Sage Science), and then sequencing adapters supplied in the SQK-LSK109 kit were attached to the DNA ends. Raw data collected as FAST5 files were converted to FASTQ format using guppy 4.5.3 (ONTs). Base-called data passing quality control (quality score $\geq 9$ ) was aligned to the hg19 human reference genome using Minimap2 (version 2.17) (github.com/lh3/minimap2). SVs were called with Sniffles (version 1.0.11) (github. com/fritzsedlazeck/Sniffles), and the major types of SVs included deletion, insertion, duplication, inversion, and TRA. Further annotation of SVs was carried out using ANNOVAR ${ }^{15}$ (github.com/WGLab/doc-ANNOVAR), combining public databases such as 1,000 Genome Phase $3,{ }^{16}$ DGV gold standard $\mathrm{CNV},{ }^{17,18} \mathrm{dbVar}$ nstd $37,{ }^{18}$ and DECIPHER. ${ }^{19}$

PCR primers were designed to detect the translocation breakpoints for this family. Primer3web (version 4.1.0, primer3.ut.ee/) was used for primer design. The sequences of 

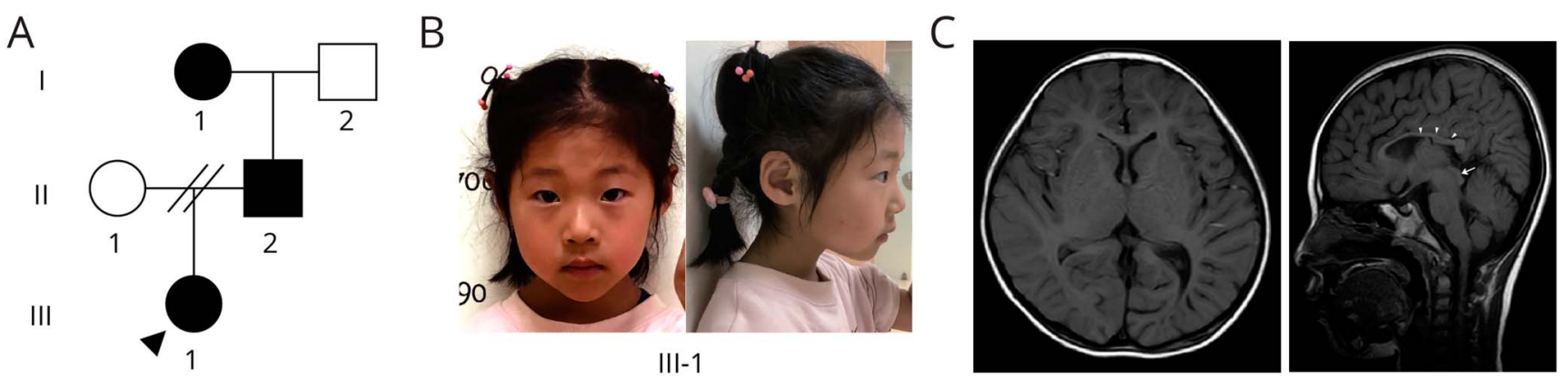

(A) The pedigree of three family members with Shashi-Pena Syndrome and the marriage Status of the proband's parents (II - 1 and II - 2). Black arrow, proband; filled Symbol, patient with Shashi-Pena Syndrome. (B) Proband at 5 years 11 months. Note the hypertelorism, arched eyebrows, and abnormal shape of the ears. (C) Brain MRI of the patient at 5 years 11 months of age. Axial image shows periventricular leukomalacia. Sagittal image shows myelination delay (white arrow) and thin corpus callosum (white arrowhead).

the breakpoint PCR primers in this study are listed in eTable 1, links.lww.com/NXG/A487. PCR products were electrophoresed on a $1.0 \%$ agarose gel, and the single, clear bands from normal and derivative chromosomes were further analyzed by Sanger sequencing on an ABI3730XL sequencer (Thermo Fisher Scientific).

Total RNA was extracted from the peripheral blood of the family members (I-1, I-2, II-2, and III-1), according to the manufacturer's specifications. The primer sequences were designed in the laboratory and synthesized by TsingKe Biotech based on the mRNA sequences obtained from the NCBI database in eTable 1, links.lww.com/ NXG/A487. The expression levels of the mRNAs were normalized to ACTB and were calculated using the $2^{-\Delta \Delta \mathrm{Ct}}$ method, a convenient way to analyze the relative changes in gene expression from real-time quantitative PCR experiments.

\section{Statistical Analysis}

We used the $t$ test to detect the mRNA expression difference between patients and control. Values of $p<0.05$ were considered statistically significant.

\section{Data Availability}

The data sets used and analyzed during this study are available from the corresponding authors upon reasonable request.

\section{Results}

\section{Patient Characteristics and Clinical Tests}

The proband (III-1) is a 6-year-old girl who came to our attention at the age of 3 because of speech delay (F). She was born at $39^{+5}$ weeks of gestation without any complications via Cesarean operation. Her birth length was $49 \mathrm{~cm}$, and her birth weight was 2,715 g. The Apgar score was 6 points (color: acrocyanotic; heart rate: $>100 / \mathrm{min}$; reflex irritability: grimace; muscle tone: some flexion; respiration: weak cry, hypoventilation) in the first minute and 8 points (color: completely pink; heart rate: $>100 / \mathrm{min}$; reflex irritability: grimace; muscle tone: some flexion; respiration: good, crying) in the first 5 minutes. She was sent to the NICU because of neonatal feeding difficulties (HP_0011968) and pneumonia in the first week.

The recognizable pattern of features and the corresponding Human Phenotype Ontology terms seen in the proband (III-1) include short stature (HP_0008848), arched eyebrows (HP_ 0002553), hypertelorism (HP_0000316), and low-set abnormally shaped ears (HP_0000369) (Figure 1B, Table 1). Examination of her growth parameters showed severe growth retardation during the first 5 years 11 months (weight $<$ third percentile, length $<15$ th percentile, height $<15$ th percentile, occipitofrontal head circumference $<$ third percentile). Her developmental delay (HP_0001263) was severe, and the intellectual disability (HP_0001249) and speech delay were moderate via the Wechsler Intelligence test and Peabody test (GMQ76/P5, FMQ 85/P16, TMQ78/P7, and SM:8, IQ = 62). A wrist X-ray examination showed osteoporosis. Her heart showed mild mitral regurgitation and mild tricuspid regurgitation (HP_0030680) on an echocardiograph examination. Left cerebral ventriculomegaly, myelination delay, thin corpus callosum, and periventricular leukomalacia were found, and the width of the posterior angle of the left lateral ventricle was $\sim 1.17 \mathrm{~cm}$ on brain MRI (Figure 1C). Additional biochemical assays were performed on the proband. Her fasting blood glucose value, levels of cholesterol, triglycerides, and chlorine, thyroid-stimulating hormone, free triiodothyronine (FT3), free thyroxine (FT4), growth hormone, insulin, serum iron, serum copper, ceruloplasmin, serum zinc, serum magnesium, and serum calcium were at normal levels. An investigation of liver function showed that the aminotransferases (aspartate aminotransferase and alanine aminotransferase) and other biochemistry were normal.

A further study was conducted on the family members to trace the source of the complex TRA. Peripheral blood DNA of the family (I-1, I-2, and II-2) was collected, and a balanced translocation $\mathrm{t}(2 ; 11)$ (p23; q23) was identified by chromosome karyotyping in I-1 and II-2. The results of PCR and 
Table 1 Clinical Features From Affected Members in the Family Comparison to ASXL2-Associated Disorders in Previous Report

\begin{tabular}{lllll}
\hline Clinical findings & III-1 & II-2 & I-1 & ASXL2 mutation in previous report $^{\mathbf{3}}$ \\
\hline Facial features & $\begin{array}{l}\text { Hypertelorism, arched } \\
\text { eyebrows }\end{array}$ & $\begin{array}{l}\text { Arched } \\
\text { eyebrows }\end{array}$ & Normal & $\begin{array}{l}\text { Hypertelorism, arched eyebrows, prominent } \\
\text { eyes, ptosis of eyelids, epicanthal folds, } \\
\text { prominent glabella, synophrys, small upper } \\
\text { vermilion, and broad nasal tip }\end{array}$ \\
\hline Ears & Low-set & Normal & Normal & $\begin{array}{l}\text { Posteriorly rotated, low-set, cupped, } \\
\text { overfolded, and thick ear lobes. }\end{array}$ \\
\hline
\end{tabular}

\begin{tabular}{ll}
\hline Growth & At 5 y $11 \mathrm{mo}$ : severe growth \\
parameters at & retardation \\
last & \\
examination &
\end{tabular}

\section{Weight $<3$ rd}

percentile,

\begin{tabular}{|c|c|c|c|c|}
\hline \multicolumn{5}{|l|}{$\begin{array}{l}\text { Length/height } \\
<15 \text { th } \\
\text { percentile, }\end{array}$} \\
\hline $\begin{array}{l}\text { Occipitofrontal } \\
\text { head } \\
\text { circumference } \\
<3 \text { rd percentile }\end{array}$ & Normal & Normal & $\begin{array}{l}\text { Normal height and weight, } \\
\text { occipitofrontal head } \\
\text { circumference }>97 \text { th percentile } \\
\text { (macrocephaly) }\end{array}$ & \\
\hline $\begin{array}{l}\text { Feeding } \\
\text { difficulties }\end{array}$ & Present only shortly after birth & $\begin{array}{l}\text { Present only } \\
\text { shortly after } \\
\text { birth }\end{array}$ & No record & Present only in neonatal period \\
\hline Hypotonia & None & None & None & Present \\
\hline $\begin{array}{l}\text { Episodes of } \\
\text { hypoglycemia }\end{array}$ & None & None & None & $\begin{array}{l}\text { Has required continuous feeding since neonatal } \\
\text { period, episodic, starting at } 2.5 \text { y of age }\end{array}$ \\
\hline Seizures & None & None & None & Febrile and nonfebrile, suspected \\
\hline Skin & Normal & Normal & Normal & $\begin{array}{l}\text { Glabellar nevus flammeus; capillary } \\
\text { malformations on trunk, neck, and behind ears; } \\
\text { deep palmar creases }\end{array}$ \\
\hline $\begin{array}{l}\text { Developmental } \\
\text { delay }\end{array}$ & Severe & Normal & Normal & Severe \\
\hline $\begin{array}{l}\text { Intellectual } \\
\text { disability }\end{array}$ & Moderate & Mild & Normal & Severe \\
\hline Delayed speech & Moderate & Normal & Normal & Severe \\
\hline Peabody & $\begin{array}{l}\text { GMQ 76/P5, FMQ 85/P16, TMQ } \\
\text { 78/P7 }\end{array}$ & Not available & Not available & Not available \\
\hline $\begin{array}{l}\text { Wechsler } \\
\text { intelligence test }\end{array}$ & SM: $8, I Q=62$ & Not available & Not available & Not available \\
\hline $\begin{array}{l}\text { Congenital } \\
\text { heart disease }\end{array}$ & $\begin{array}{l}\text { Mild mitral regurgitation, mild } \\
\text { tricuspid regurgitation }\end{array}$ & Normal & Normal & $\begin{array}{l}\text { Atrial septal defect, patent ductus arteriosus, } \\
\text { left ventricular dysfunction }\end{array}$ \\
\hline Brain MRI & $\begin{array}{l}\text { Myelination delay, thin corpus } \\
\text { callosum and PVL, left cerebral } \\
\text { ventriculomegaly } \sim 1.17 \mathrm{~cm}\end{array}$ & Not available & Not available & $\begin{array}{l}\text { Increased extra-axial cerebral space, white- } \\
\text { matter volume loss, increased extra-axial } \\
\text { cerebral space, choroid plexus papilloma, }\end{array}$ \\
\hline $\begin{array}{l}\text { Skeletal and/or } \\
\text { extremity } \\
\text { manifestations }\end{array}$ & Osteopenia & Normal & Normal & $\begin{array}{l}\text { Increased density of alveolar bone, advanced } \\
\text { bone age, kyphosis, scoliosis, multiple bilateral } \\
\text { fractures, overlappings, and fourth toes }\end{array}$ \\
\hline
\end{tabular}

Abbreviation: PVL = periventricular leukomalacia.

Sanger sequencing showed that these sequences were the same in I-1, II-2, and III-1. The karyotype of the proband is $\mathrm{t}(2 ; 11)$ (p23; q23), and this TRA was inherited from her grandmother (Figure $2 \mathrm{~A}$ ).
The father (II-2) was $172 \mathrm{~cm}$ tall and $74 \mathrm{~kg}$ at the age of 35 , and the clinical features include arched eyebrows (HP_0002553), feeding difficulties (HP_0011968), and moderate verbal comprehension during communication. No bruising, cuts, or lumps were found in 
Figure 2 Karyotype Analysis and Composition of the Derivative Chromosomes in a Balanced Translocation, With the Precise Coordinates of Breakpoints Detected and Confirmed by Sanger Sequencing

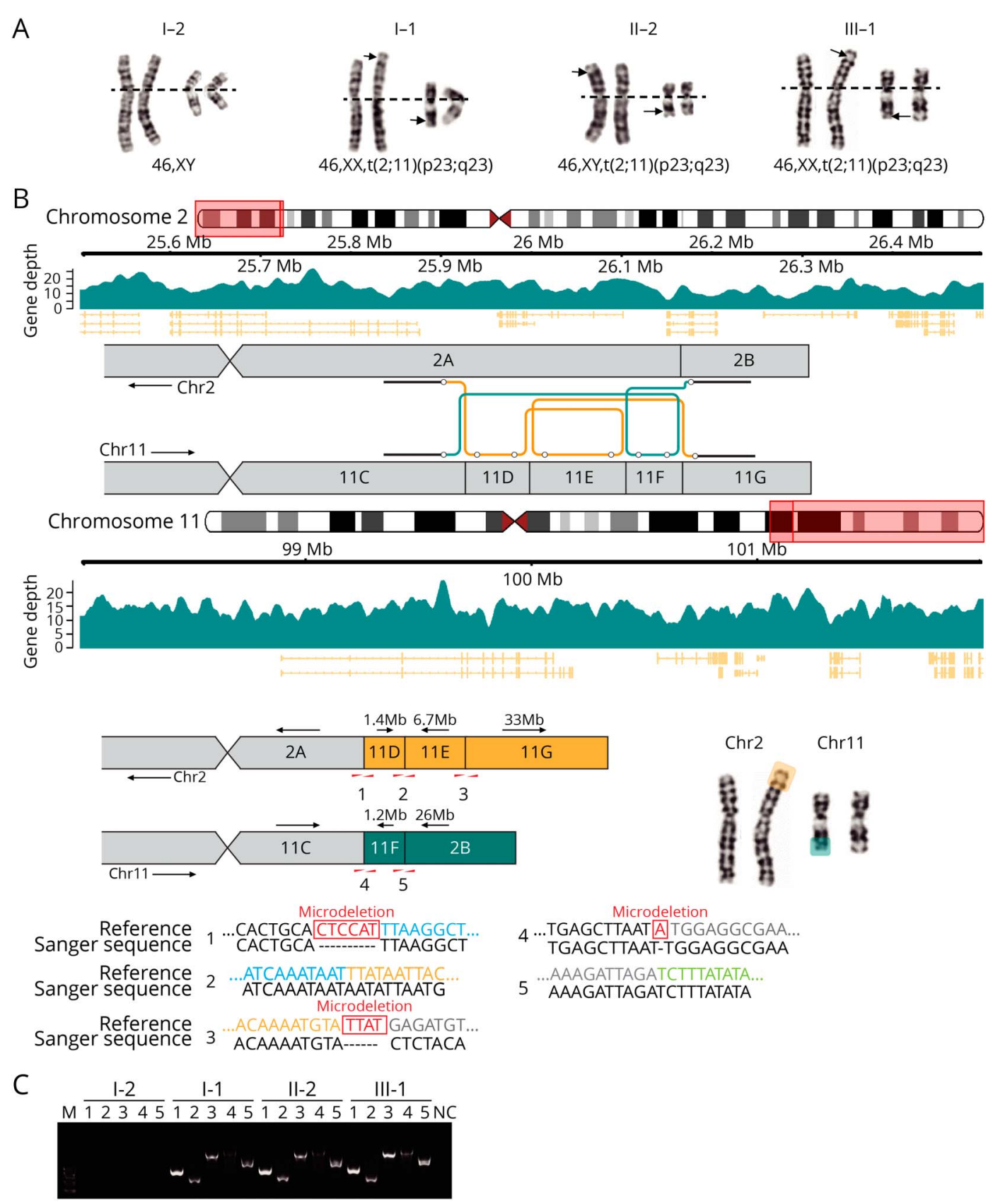

(A) Conventional G-banded partial karyotypes in the family members. (B) The "Subway" plot Shows how each region is connected and allows for reconstruction of the new DNA sequence and gene order in the individual, and the subsequent karyotype reveals a complex translocation involving chromosomes 2 and 11. Breakpoints were confirmed by Sanger sequencing, and microdeletions were detected. Primers 1, 2, 3, 4, and 5 (red arrow heads). (C) PCR validation shows that the variant was caused by balanced translocation in the family (I-1, I-2, II-2, and III-1). No bands were detected in the proband's grandfather (I-2). PCR products of three patients and one normal control are shown (DL2,000 DNA Marker).

his skin; seizures and episodes of hypoglycemia have never appeared, and he was movement barrier-free as found by visual examination. The grandmother was $156 \mathrm{~cm}$ tall and $57.3 \mathrm{~kg}$ at 65 years old, and she was thin and short in childhood. No redness, swelling, deformity, and movement barrier were found by visual examination, and seizures and episodes of hypoglycemia have never appeared. Developmental delay and intellectual disability are not known in her childhood, but her talk and verbal comprehension are normal. In summary, the phenotypes of the 3 patients are similar to Shashi-Pena syndrome caused by ASXL2 mutants (Table 1).

\section{Complex Chromosome Rearrangements Found by Nanopore Sequencing}

Next, we performed whole genome long-read sequencing analysis on the proband (III-1) and used different analytical strategies and tools to analyze the translocation breakpoints. 


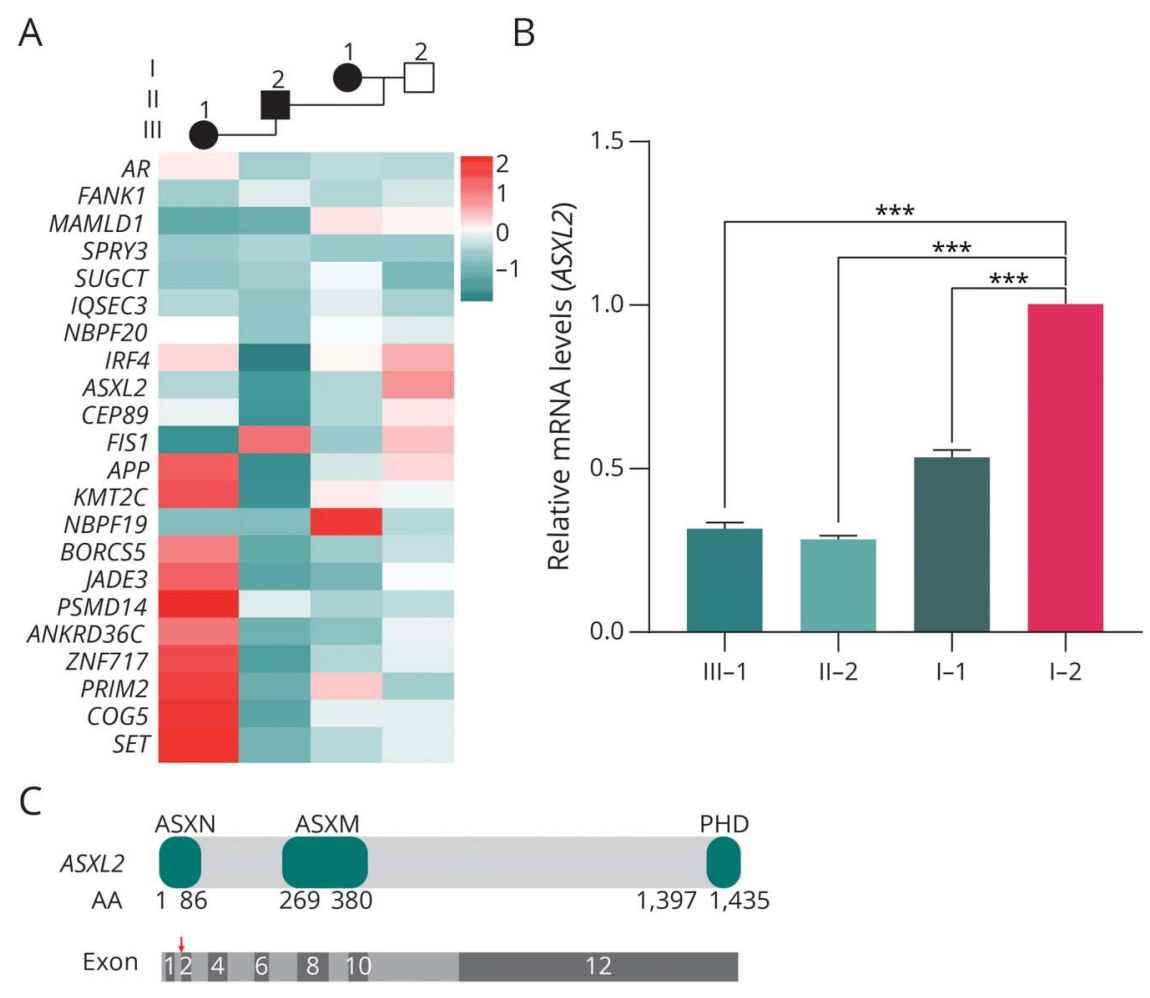

(A) Correlation heatmap of candidate gene distribution between patients and I-2. Pedigrees of the family members are shown above the heatmap. (B) qPCR showing downregulation of ASXL2 in the patients compared with I-2. Data are presented as mean \pm SEM. Comparisons between two groups were performed by two-tailed unpaired Student's $t$ test $(p<0.0001)$. (C) Schematic structure of ASXL2 depicting the break point (Chr2:26068500, red arrow) identified in the patients. ASXN, ASXM, and PHD-type zinc-finger domains are represented as dark-green boxes in ASXL2 protein. The amino acid (AA) positions of all domains, as well as a schematic representation of the exons encoding the above depicted part of the protein, are given underneath.
SVs including 102 translocations and 145 inversions were found in the proband (III-1) at an average of $15 \times$ of the whole genome, and the balanced translocation was confirmed as $\mathrm{t}(2$; 11) (p23.3; q22.1) based on the karyotyping results. Our analysis workflow successfully detected the complex SV breakpoints in the proband (III-1) and confirmed the karyotype as 46,XX,t $(2 ; 11)(\mathrm{p} 23 ; \mathrm{q} 23)$ pat.Seq[GRCh37] $\operatorname{der}(2) \mathrm{t}(2$; 11) (p23.3; q22.1)del(q22.1)inv(11) (q22.1), der(11)t(2; 11) (p23.3; q22.1),ins(11) (q22.1).g[chr11:pter_101817177:chr11: 99900659_100571704:chr11:99900660_98496146:chr2: 26068500_cen_qter].g[chr11:pter_cen_98496149:chr11: 101817176_100571719:chr2:26068500_qter] (Figure 2B). The coordinates of the predicted breakpoints that correlated with the cytogenetic report and the nanopore results showed the extent of concordance of the predicted breakpoints with the Sanger sequencing results (Figure 2C). There were discrepancies of a few bases because of microdeletions in all the samples, and Sanger sequencing confirmed the microdeletions.

Complex chromosome rearrangements affecting ASXL2 as a pathogenic mechanism of Shashi-Pena syndrome.

In our target regions, an ONT analysis showed 3 breakpoints in the complex balanced translocation and inversions affecting ASXL2 (eTable 2, links.lww.com/NXG/A487). The RNA-seq was conducted on peripheral blood of the family members, and the average mRNA expression of ASXL2 decreased among the patients ( $t$ test, $p=0.0387$ ) (Figure 3A). Furthermore, the
qPCR showed that the mRNA expression of ASXL2 decreased in the patients, consistent with the RNA-seq results (unpaired $t$ test, $p<0.0001$ ) (Figure 3B). In conclusion, truncating variants in ASXL2 via a complex TRA t $(2 ; 11)$ (p23.3; q22.1) underlie Shashi-Pena syndrome (MIM:617,190) with a clinically recognizable phenotype (Figure 3C).

In summary, the karyotype $\mathrm{t}(2 ; 11)$ (p23.3; q22.1) divides ASXL2 into 2 parts, affecting its expression and leading to Shashi-Pena syndrome in a Chinese family. This case study suggests that nanopore sequencing is suitable for the pathogenic analysis of complex rearrangements, providing new avenues for the diagnosis of agnogenic diseases.

\section{Discussion}

Genomic SVs, including translocations, inversions, insertions, deletions, and duplications, are challenging to detect reliably using traditional genomic technologies. ${ }^{20-22}$ In particular, balanced translocations and inversions cannot be identified by microarrays or by short-read sequencing. ${ }^{23}$ The precise localization of breakpoints is vital for exploring genetic causes in patients with balanced translocations or inversions. ${ }^{24}$ Longread sequencing techniques may detect these structural variants in a more direct, efficient, and accurate manner. ${ }^{25}$

In this study, we identified 3 patients in a family with a complex SV, $\mathrm{t}(2 ; 11)$ with breakpoints at $\mathrm{p} 23.3$ and $\mathrm{q} 22.1$, and 
identified possible candidate genes by Oxford Nanopore Technology. Using RNA-seq and qPCR, we found that the breakpoints disrupted ASXL2 gene expression and finally concluded that a complex rearrangement of the chromosomes decreased the mRNA expression of ASXL2 in the patients and led to a rare autosomal-dominant neurodevelopmental syndrome, Shashi-Pena syndrome. Shashi-Pena syndrome, reported in 2016 in the United States, ${ }^{3}$ is caused by ASXL2 mutations and shows the common clinical features of developmental disabilities, intellectual disability, delayed speech, and some facial features. However, differences were found between cases, such as the level of intellectual disability, congenital heart disease, and brain MRI, which may be because of different mutation types or incomplete penetrance.

We report a case of Shashi-Pena syndrome caused by a balanced translocation in a Chinese family, which expands the mutation spectrum of ASXL2 and increases the number of reported patients, and the results could allow better counseling for patients. More clinical reports of individuals with damaging ASXL2 variants and related clinical features will provide further clarity in the future.

\section{Acknowledgment}

We would like to thank the affected individuals and the family for permitting us to publish this information and GrandOmics Biosciences for providing technical support. We thank Catherine Perfect, MA (Cantab), from Liwen Bianji (Edanz) (liwenbianji. $\mathrm{cn} /$ ) for editing the English text of a draft of this manuscript.

\section{Study Funding}

This work was supported by grants from National Key R\&D Program of China (No. 2018YFC1002402 to Z.X.) and the National Natural Science Foundation of China (No. 81770236 and 81971398).

\section{Disclosure}

Y. Wang, J. Tan, Y. Wang, A. Liu, F. Qiao, M. Huang, C. Zhang, and J. Zhou report no disclosures relevant to the manuscript. P. Hu is funded by National Natural Science Foundation of China (81971398). Z. Xu is funded by National Key R\&D Program of China (2018YFC1002402) and National Natural Science Foundation of China (81770236). Go to Neurology.org/NG for full disclosures.

\section{Publication History}

Received by Neurology: Genetics April 26, 2021. Accepted in final form September 14, 2021.

\section{Appendix Authors}

\begin{tabular}{lll}
\hline Name & Location & Contribution \\
\hline $\begin{array}{l}\text { Ya Wang, } \\
\text { PhD }\end{array}$ & $\begin{array}{l}\text { Nanjing Maternity and Child } \\
\text { Health Care Hospital, } \\
\text { Nanjing, China }\end{array}$ & $\begin{array}{l}\text { Data analysis and drafted the } \\
\text { manuscript }\end{array}$ \\
\hline $\begin{array}{l}\text { Jianxin } \\
\text { Tan, PhD }\end{array}$ & $\begin{array}{l}\text { Nanjing Maternity and Child } \\
\text { Health Care Hospital, } \\
\text { Nanjing, China }\end{array}$ & $\begin{array}{l}\text { Clinical genetic evaluation and } \\
\text { reviewed the manuscript }\end{array}$ \\
& & \\
\hline
\end{tabular}

Appendix (continued)

\begin{tabular}{|c|c|c|}
\hline Name & Location & Contribution \\
\hline $\begin{array}{l}\text { Yan Wang, } \\
\text { PhD }\end{array}$ & $\begin{array}{l}\text { Nanjing Maternity and Child } \\
\text { Health Care Hospital, } \\
\text { Nanjing, China }\end{array}$ & $\begin{array}{l}\text { Clinical genetic evaluation and } \\
\text { reviewed the manuscript }\end{array}$ \\
\hline An Liu, MD & $\begin{array}{l}\text { Nanjing Maternity and Child } \\
\text { Health Care Hospital, } \\
\text { Nanjing, China }\end{array}$ & $\begin{array}{l}\text { Molecular data acquisition } \\
\text { and interpretation }\end{array}$ \\
\hline $\begin{array}{l}\text { Fengchang } \\
\text { Qiao, PhD }\end{array}$ & $\begin{array}{l}\text { Nanjing Maternity and Child } \\
\text { Health Care Hospital, } \\
\text { Nanjing, China }\end{array}$ & $\begin{array}{l}\text { Molecular data acquisition } \\
\text { and interpretation }\end{array}$ \\
\hline $\begin{array}{l}\text { Mingtao } \\
\text { Huang, } \\
\text { PhD }\end{array}$ & $\begin{array}{l}\text { Nanjing Maternity and Child } \\
\text { Health Care Hospital, } \\
\text { Nanjing, China }\end{array}$ & Bioinformatics analysis \\
\hline $\begin{array}{l}\text { Cuiping } \\
\text { Zhang, MD }\end{array}$ & $\begin{array}{l}\text { Nanjing Maternity and Child } \\
\text { Health Care Hospital, } \\
\text { Nanjing, China }\end{array}$ & Molecular data acquisition \\
\hline $\begin{array}{l}\text { Jing Zhou, } \\
\text { MD }\end{array}$ & $\begin{array}{l}\text { Nanjing Maternity and Child } \\
\text { Health Care Hospital, } \\
\text { Nanjing, China }\end{array}$ & Molecular data acquisition \\
\hline $\begin{array}{l}\text { Ping Hu, } \\
\text { PhD }\end{array}$ & $\begin{array}{l}\text { Nanjing Maternity and Child } \\
\text { Health Care Hospital, } \\
\text { Nanjing, China }\end{array}$ & $\begin{array}{l}\text { Funded the project and } \\
\text { supervised and managed the } \\
\text { study }\end{array}$ \\
\hline $\begin{array}{l}\text { Zhengfeng } \\
\text { Xu, MD }\end{array}$ & $\begin{array}{l}\text { Nanjing Maternity and Child } \\
\text { Health Care Hospital, } \\
\text { Nanjing, China }\end{array}$ & $\begin{array}{l}\text { Funded the project, } \\
\text { interpreted the data, and } \\
\text { drafted the manuscript }\end{array}$ \\
\hline
\end{tabular}

\section{References}

1. Fisher CL, Berger J, Randazzo F, Brock HW. A human homolog of Additional sex combs, ADDITIONAL SEX COMBS-LIKE 1, maps to chromosome 20q11. Gene. 2003;306(1-2):115-126.

2. Katoh M. Functional proteomics of the epigenetic regulators ASXL1, ASXL2 and ASXL3: A convergence of proteomics and epigenetics for translational medicine. Expert Rev Proteomics. 2015;12(3):317-328.

3. Shashi V, Pena LDM, Kim K, et al. De novo truncating variants in ASXL2 are associated with a unique and recognizable clinical phenotype. Am J Hum Genet. 2016; 99(4):991-999.

4. Kitamura T. ASXL1 mutations gain a function. Blood. 2018;131(3):274-275.

5. Asada S, Fujino T, Goyama S, Kitamura T. The role of ASXL1 in hematopoiesis and myeloid malignancies. Cell Mol Life Sci. 2019;76(13):2511-2523.

6. Hoischen A, Van Bon BWM, Rodríguez-Santiago B, et al. De novo nonsense mutations in ASXL1 cause Bohring-Opitz syndrome. Nat Genet. 2011;43(8): 729-731.

7. Lichtig H, Artamonov A, Polevoy H, Reid CD, Bielas SL, Frank D. Modeling bainbridge-ropers syndrome in Xenopus laevis embryos. Front Physiol. 2020;11:1-11.

8. Ha P, Campagne A, Lee M, et al. BAP1 complex promotes transcription by opposing. Nat Commun. 2019;10(1):1-15

9. $\mathrm{Lu} \mathrm{H}$, Giordano F, Ning Z. Oxford nanopore MinION sequencing and genome Assembly. Genomics Proteomics Bioinformatics. 2016;14(5):265-279.

10. Barseghyan H, Tang W, Wang RT, et al. Next-generation mapping: A novel approach for detection of pathogenic structural variants with a potential utility in clinical diagnosis. Genome Med. 2017;9(1):1-11.

11. Madjunkova S, Sundaravadanam Y, Antes R, et al. Detection of structural rearrangements in embryos. N Engl J Med. 2020;382(25):2472-2474.

12. Ishiura H, Doi K, Mitsui J, et al. Expansions of intronic TTTCA and TTTTA repeats in benign adult familial myoclonic epilepsy. Nat Genet. 2018;50(4): 581-590.

13. Wu TP, Wang $\mathrm{T}$, Seetin MG, et al. DNA methylation on $\mathrm{N}(6)$-adenine in mammalian embryonic stem cells. Nature. 2016;532(7599):329-333.

14. Warburton D. De novo balanced chromosome rearrangements and extra marker chromosomes identified at prenatal diagnosis: clinical significance and distribution of breakpoints. Am J Hum Genet. 1991;49(5):995-1013.

15. Wang $\mathrm{K}, \mathrm{Li} \mathrm{M}, \mathrm{Hakonarson} \mathrm{H}$. ANNOVAR: functional annotation of genetic variants from high-throughput sequencing data. Nucleic Acids Res. 2010;38(16):1-7.

16. Sudmant $\mathrm{PH}$, Rausch $\mathrm{T}$, Gardner EJ, et al. An integrated map of structural variation in 2,504 human genomes. Nature. 2015;526(7571):75-81.

17. MacDonald JR, Ziman R, Yuen RKC, Feuk L, Scherer SW. The database of genomic variants: A curated collection of structural variation in the human genome. Nucleic Acids Res. 2014;42(D1):986-992. 
18. Lappalainen I, Lopez J, Skipper L, et al. DbVar and DGVA: public archives for genomic structural variation. Nucleic Acids Res. 2013;41(D1):936-941.

19. Firth HV, Richards SM, Bevan AP, et al. DECIPHER: database of chromosomal imbalance and phenotype in humans using ensembl resources. Am J Hum Genet. 2009; 84(4):524-533.

20. Feuk L, Carson AR, Scherer SW. Structural variation in the human genome. Nat Rev Genet. 2006;7(2):85-97.

21. Collins RL, Brand H, Redin CE, et al. Defining the diverse spectrum of inversions, complex structural variation, and chromothripsis in the morbid human genome. Genome Biol. 2017;18(1):1-21.
22. Conrad DF, Pinto D, Redon R, et al. Origins and functional impact of copy number variation in the human genome. Nature. 2010;464(7289):704-712.

23. Hu L, Liang F, Cheng D, et al. Location of balanced chromosome-translocation breakpoints by long-read sequencing on the Oxford nanopore platform. Front Genet. 2020;10:1313.

24. Dutta UR, Rao SN, Pidugu VK, et al. Breakpoint mapping of a novel de novo translocation $\mathrm{t}(\mathrm{X} ; 20)(\mathrm{q} 11.1 ; \mathrm{p} 13)$ by positional cloning and long read sequencing. Genomics. 2019;111(5):1108-1114.

25. Shi L, Guo Y, Dong C, et al. Long-read sequencing and de novo assembly of a Chinese genome. Nat Commun. 2016;7:12065. 


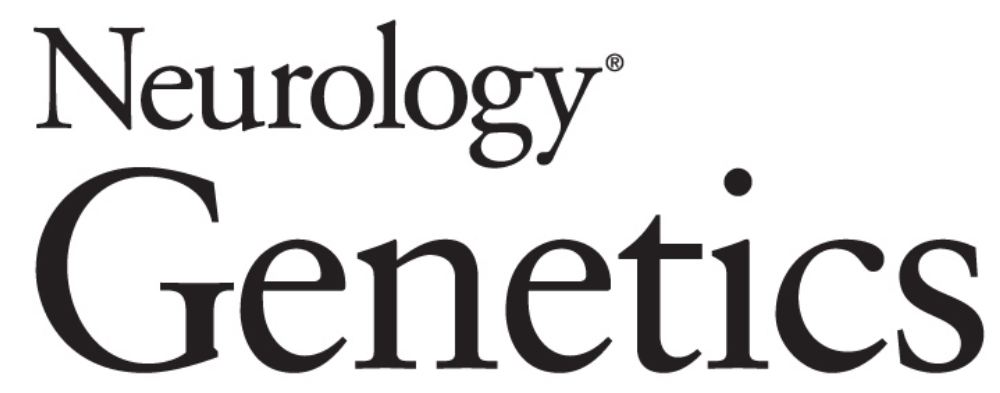
Diagnosis of Shashi-Pena Syndrome Caused by Chromosomal Rearrangement Using Nanopore Sequencing
Ya Wang, Jianxin Tan, Yan Wang, et al. Neurol Genet 2021;7;
DOI 10.1212/NXG.0000000000000635

This information is current as of November 23, 2021

Neurol Genet is an official journal of the American Academy of Neurology. Published since April 2015, it is an open-access, online-only, continuous publication journal. Copyright Copyright ( 2021 The Author(s). Published by Wolters Kluwer Health, Inc. on behalf of the American Academy of Neurology.. All rights reserved. Online ISSN: 2376-7839.

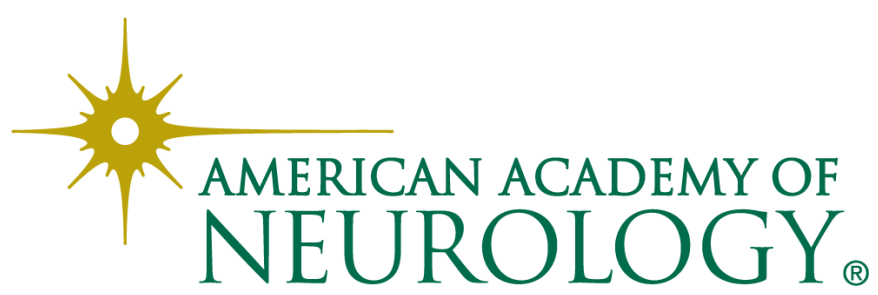




\section{Updated Information \& Services}

\section{References}

\section{Subspecialty Collections}

\section{Permissions \& Licensing}

\section{Reprints}

including high resolution figures, can be found at: http://ng.neurology.org/content/7/6/e635.full.html

This article cites 25 articles, 1 of which you can access for free at: http://ng.neurology.org/content/7/6/e635.full.html\#\#ref-list-1

This article, along with others on similar topics, appears in the following collection(s):

Association studies in genetics

http://ng.neurology.org//cgi/collection/association_studies_in_genetics Chromosomes

http://ng.neurology.org//cgi/collection/chromosomes

Developmental disorders

http://ng.neurology.org//cgi/collection/developmental_disorders

Gene expression studies

http://ng.neurology.org//cgi/collection/gene_expression_studies

\section{Mental retardation}

http://ng.neurology.org//cgi/collection/mental_retardation

Information about reproducing this article in parts (figures,tables) or in its entirety can be found online at:

http://ng.neurology.org/misc/about.xhtml\#permissions

Information about ordering reprints can be found online:

http://ng.neurology.org/misc/addir.xhtml\#reprintsus

Neurol Genet is an official journal of the American Academy of Neurology. Published since April 2015, it is an open-access, online-only, continuous publication journal. Copyright Copyright $\odot 2021$ The Author(s). Published by Wolters Kluwer Health, Inc. on behalf of the American Academy of Neurology.. All rights reserved. Online ISSN: 2376-7839.

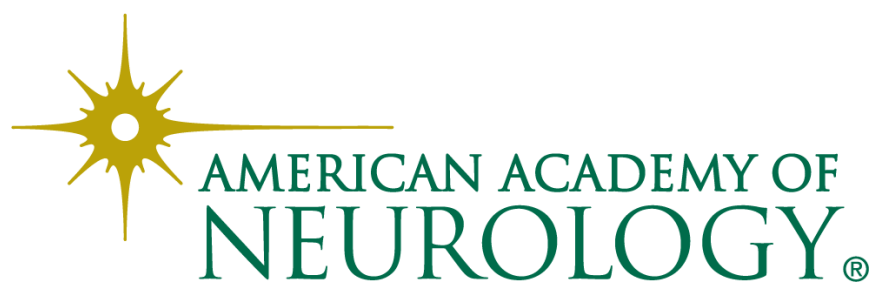

